University of Nebraska - Lincoln

DigitalCommons@University of Nebraska - Lincoln

\title{
Biology and management of Plodia interpunctella (Lepidoptera: Pyralidae) in stored products
}

\author{
S. Mohandass \\ Kansas State University \\ F. H. Arthur \\ USDA-ARS, frank.arthur@ars.usda.gov \\ K. Y. Zhu \\ Kansas State University, kzhu@ksu.edu \\ James E. Throne \\ USDA-ARS, james.throne@ars.usda.gov
}

Follow this and additional works at: https://digitalcommons.unl.edu/usdaarsfacpub

Mohandass, S.; Arthur, F. H.; Zhu, K. Y.; and Throne, James E., "Biology and management of Plodia interpunctella (Lepidoptera: Pyralidae) in stored products" (2007). Publications from USDA-ARS / UNL Faculty. 1981.

https://digitalcommons.unl.edu/usdaarsfacpub/1981

This Article is brought to you for free and open access by the U.S. Department of Agriculture: Agricultural Research Service, Lincoln, Nebraska at DigitalCommons@University of Nebraska - Lincoln. It has been accepted for inclusion in Publications from USDA-ARS / UNL Faculty by an authorized administrator of DigitalCommons@University of Nebraska - Lincoln. 
Review

\title{
Biology and management of Plodia interpunctella (Lepidoptera: Pyralidae) in stored products ${ }^{\text {is }}$
}

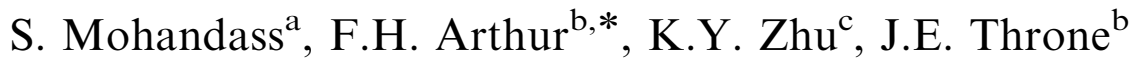 \\ ${ }^{a}$ Department of Architecture, Planning, and Design, Kansas State University, Manhattan, KS, USA \\ ${ }^{\mathrm{b}}$ USDA-ARS, Grain Marketing and Production Research Center, 1515 College Avenue, Manhattan, KS-66506, USA \\ ${ }^{\mathrm{c}}$ Department of Entomology, Kansas State University, Manhattan, KS, USA
}

Accepted 10 August 2006

\begin{abstract}
Plodia interpunctella (Hübner), the Indian meal moth, is a world-wide insect pest of stored-products and processed food commodities. It can infest a variety of products and is perhaps the most economically important insect pest of processed food. In this review, we summarize the biology of $P$. interpunctella, discuss oviposition and development in relation to temperature, environment and food source, examine studies involving sampling and detection, describe various aspects of integrated control, summarize the current knowledge regarding management of $P$. interpunctella, and address potential areas for new research. The use of reduced-risk insecticides, non-chemical control, targeted pest management through spatial analysis and other means of identifying specific locations of infestations, and computer models that simulate population growth, are examples of some of those new areas of research.
\end{abstract}

Published by Elsevier Ltd.

Keywords: Plodia interpunctella; Biology; Control; Research

\section{Contents}

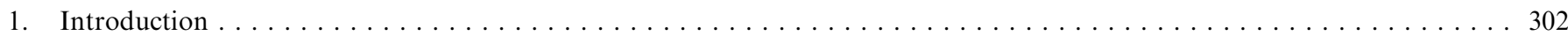

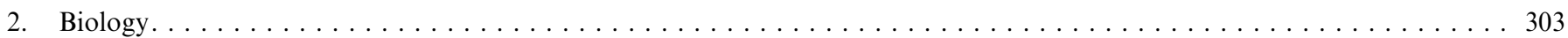

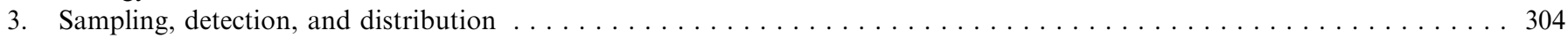

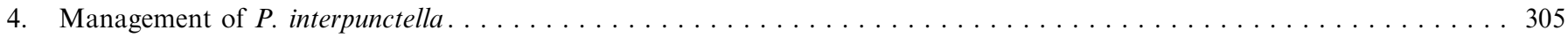

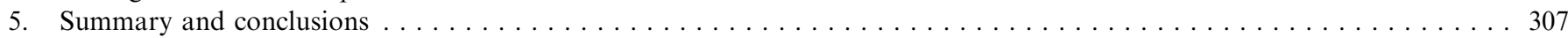

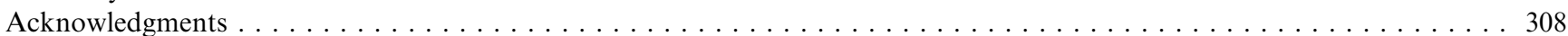

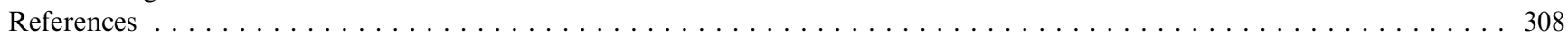

This document reports the results of research only. Mention of a proprietary product or trade name does not constitute a recommendation or endorsement by the United Sates Department of Agriculture or by Kansas State University.

*Corresponding author. Tel.: + 7857762783 ; fax: +7855375584 .

E-mail address: frank.arthur@gmprc.ksu.edu (F.H. Arthur).

\section{Introduction}

The Indian meal moth, Plodia interpunctella (Hübner), is a major economic insect pest of stored products and is found on every continent except Antarctica (Rees, 2004). There are no records suggesting that $P$. interpunctella could migrate or disperse over continental distances. However, $P$. interpunctella has been found within infested commodities in commercial ocean freight shipments (Schulten and 
Roorda, 1984) and in food products imported into the United Kingdom from Africa (Cox, 1979).

One of the first comprehensive scientific studies of $P$. interpunctella was undertaken by Hamlin et al. (1931), who categorized the insect as a pest of grain, grain-based crops, and more than 20 different nuts, fruits, and candies from the agricultural system in the state of California in the United States of America (USA). They also described the economic consequences of infestations through returned infested products. The products or groups of products that have been reported to be infested by $P$. interpunctella are listed in several publications (Johnson et al., 1992, 1995; Sedlacek et al., 1996; Nansen and Phillips, 2003, 2004; Nansen et al., 2004a). Plodia interpunctella is an external feeder. The larvae continuously spin a silken web both inside and on top of the food surface, and feed within the web. The webbing contains larval excreta (frass) and exuvia (cast skins), and gives an unpleasant odor to the infested commodity. The infested commodity is sometimes covered on the surface with a thick mat of silken webbing. Infestations of $P$. interpunctella can cause direct product loss and indirect economic costs through pest control costs, quality losses, and consumer complaints (Phillips et al., 2000a).

In the USA, the continuing loss of chemical insecticides through regulatory action, new laws and interpretations of those laws, economic costs of pesticide regulations, and consumer preferences and expectations, have important consequences for the management of $P$. interpunctella and other stored-product insects (Arthur, 1996). The impending loss of the fumigant methyl bromide through compliance with the Montreal Protocol (Anonymous, 2004) will undoubtedly further affect management programs for $P$. interpunctella, accelerating the demand for new control strategies (Phillips et al., 2000a, b). The objectives of this review are to: (1) summarize and synthesize the information regarding biology and control in a review format; and (2) to discuss potential areas of new research on management and control of $P$. interpunctella.

\section{Biology}

Plodia interpunctella is a pyralid moth in the sub-family Phycitinae. Most researchers and workers with storedproduct insects are familiar enough with the species that detailed depictions of the life stages are not needed in this review. A general description of all life stages was first given by Hamlin et al. (1931), and there are several more recent summaries and descriptions (Rees, 2004). Detailed morphological descriptions of larvae, pupae and adults were given in Richards and Thomson (1932) and in Hinton (1943), and Heinrich (1956) describes adult wing venation and genitalia of the sexes. There are five larval instars (Allotey and Goswami, 1990). Arbogast et al. (1980) describes the eggs of $P$. interpunctella as being small, with rounded excrescences and prominent carinae, and give a key for separating the eggs from those of other common stored-product insects.

Oviposition behavior in P. interpunctella is influenced by food odor (Phillips and Strand, 1994), and eggs are laid on or near the food surface, often spatially aggregated in some fashion (Mullen and Arbogast, 1977; Arbogast and Mullen, 1978). Deseo (1976) showed fecundity of $P$. interpunctella is increased by food odor and that the eggs are laid in batches near the source of the odor. Orientation of adult $P$. interpunctella towards oviposition sites could be based on primary host-derived or secondary conspecific-insect-derived chemical cues. Phillips and Strand (1994) found that adult $P$. interpunctella oriented towards food odors and laid more eggs on substrates containing food than on those without food, and more eggs were laid on dishes that contained conspecific larval secretions. The adults may lay their eggs near the food surface when the food is inaccessible due to packaging or other barriers, or when the food odors are weak (Silhacek et al., 2003). The presence of oils can also lead to an increase in oviposition of $P$. interpunctella (Nansen and Phillips, 2003). Fecundity of $P$. interpunctella differs greatly from one study to another and is dependent upon several factors, such as type of food, size of the female, provision of drinking water, and physiological state of the female moths (Mbata, 1985). As with other biological parameters for $P$. interpunctella, there is considerable variation among laboratory studies regarding fecundity. Mbata (1985) reported that maximum fecundity occurred at $30^{\circ} \mathrm{C}$, Bell (1975) documents successful breeding but not maximum fecundity at $30^{\circ} \mathrm{C}$, and Johnson et al. $(1992,1995)$ show egg laying up to $31^{\circ} \mathrm{C}$, dependent in part on the rearing diet. Environmental diurnal cycles and circadian rhythms apparently have little influence on oviposition in $P$. interpunctella, in contrast to other pyralid moth species (Bell, 1981).

The food source is obviously an important factor for determining fecundity and other biological parameters. Allotey and Goswami (1990) recorded mean fecundities of 96.8 on wheat and 174.2 on broken maize, which are much lower than the mean fecundities of 258,275 , and 280 when the young larvae were reared on walnuts, almonds, and wheat bran, respectively (Johnson et al., 1992). In laboratory experiments, the percentage egg hatch also varies according to the type of commodity used for rearing younger stages. On pistachios and almonds, the egg hatch was $88 \%$ and $96 \%$, respectively (Johnson et al., 1992), while up to $98.6 \%$ of the eggs hatched from adults whose younger stages were reared on different commodities (Allotey and Goswami, 1990). The newly hatched larvae quickly disperse to find food (Sedlacek et al., 1996), and first instars can invade cans containing food through pinholes of diameter $0.39-0.45 \mathrm{~mm}$ (Tsuji, 1998, 2000). The invasion decreased as the distance from the food source increased but a large proportion of the larvae were found inside the food, even when the food source was placed up to $38 \mathrm{~cm}$ from the release point. 
In addition to temperature (Bell, 1975), the type of commodity or food material greatly influences the time required for $P$. interpunctella to complete the life cycle (Williams, 1964; Mbata and Osuji, 1983; Subramanyam and Hagstrum, 1993; Johnson et al., 1995). At 20 and $25^{\circ} \mathrm{C} ; 70 \%$ relative humidity (r.h.), the peak emergence of adults from eggs of a laboratory strain reared on wheat feed, yeast, and bran diet was 60 and 34 days, respectively (Bell, 1975). Johnson et al. (1992) recorded development times of 22.6 days at $28.3{ }^{\circ} \mathrm{C}$ on bran compared with 31.3 , 31.4 , and 38.2 days on almonds, pistachios, and walnuts, respectively, with similar patterns at higher and lower temperatures. Egg to adult emergence required 25.7 and 46.1 days when reared at $30^{\circ} \mathrm{C}$ and $76 \%$ r.h. on broken sorghum and on wheat, respectively (Allotey and Goswami, 1990). Due to such differences in development times, different degree-day estimations may be required for egg to adult development of $P$. interpunctella reared on different commodities (Johnson et al., 1995). Different lower limits of development have also been reported by researchers (Howe, 1965; Bell, 1975; Fields, 1992; Johnson et al., 1995), ranging from 16 to $20^{\circ} \mathrm{C}$, which could also relate to variation in diet, rearing conditions, and geographic differences in particular moth strains. This variation in developmental time also contributes to the difficulty in defining individual stage-specific development time for the five larval stages. In addition, it is difficult to observe larval molts in various diets, and it is possible that frequent disturbance of the larvae to measure head capsules to find other evidence of molting may prolong development time and increase mortality.

Diapause occurs in the 5th or last instar, after feeding has ceased, but environmental cues may occur earlier in the development. Low temperatures can induce diapause (Tzanakakis, 1959; Johnson et al., 1995), as can short photoperiods (Tzanakakis, 1959; Bell and Walker, 1973). In a study by Bell (1976a), P. interpunctella entered diapause at 20 and $25^{\circ} \mathrm{C}$ when the photoperiod was less than or equal to $13 \mathrm{~h}$. Diapause can also be induced by a sudden drop in temperatures. A Nigerian strain of $P$. interpunctella entered diapause when they were reared at $30{ }^{\circ} \mathrm{C}$ up to the third instar stage and then placed at $20^{\circ} \mathrm{C}$ (Mbata, 1987). In storage facilities where temperatures are uncontrolled, $P$. interpunctella larvae may enter diapause during the colder months. When suitable conditions reoccur, a sudden increase in moth population occurs, usually during the early spring season (Mason, 2003). In some cases, diapause can be absent in geographic locations where temperatures may not be cool enough to induce it (Prevett, 1971).

Longer photoperiods and higher temperatures terminate diapause in the larvae. At $20^{\circ} \mathrm{C}$, rapid termination of diapause occurred at 16:8 (light: dark) (Bell, 1976b). The effects of density on diapause were first described by Tsuji (1959), who recorded a density-induced diapause. Bell (1976a) also recorded an increase in diapause triggered by a high rearing density in specific populations of
$P$. interpunctella. The effects of density on the induction of diapause may be determined in part by temperature and experimental conditions, and also other factors such as strain geographic origin (Bell et al., 1979), the photoperiod at specific temperatures and the cold-tolerance of individual strains (Bell, 1982).

The time required for $P$. interpunctella to complete a generation is a complex interaction of temperature, diet, and geographic strain. Emergence of $P$. interpunctella adults and several of the subsequent behaviors are related to photoperiod. In a simulated warehouse condition, upon emergence at the end of the photophase, the moths moved rapidly to the nearby walls or undersides of storage pallets (Silhacek et al., 2003). In a study under natural light/dark cycles across four seasons, Madrid and Sinha (1983) found that the initial peak period of adult movement and oviposition occurred during the early evening hours. As the age of the adults increased, this movement and oviposition became more erratic, without any definite peaks. Mating occurred within the first $24 \mathrm{~h}$ (Silhacek et al., 2003).

\section{Sampling, detection, and distribution}

Sampling of adult populations in the field can be done by a variety of methods, but the primary sampling tool is through pheromone-based trapping of males (Phillips et al., 2000a, b; Mullen and Dowdy, 2001). The pheromone commonly referred to as "ZETA" was one of the first commercial pheromones for stored-product insects, and the response of males to this pheromone has been well documented (Nansen and Phillips, 2003, 2004; Nansen et al., 2004a, b). Although pheromone traps are commonly used in monitoring studies, there are a variety of factors that can influence trap catch including but not limited to density, trap type, visual cues, pheromone composition and trap height (cited in Nansen et al., 2004a). In small shed studies, Nansen et al. (2004a) showed male moths were attracted to traps with a physical surface that simulated a landing platform, but in the absence of such a surface, traps placed low and high in the shed caught more males than other traps in the vertical grid. Trap placement therefore appears to be an important consideration when assessing storage structures for $P$. interpunctella. Larval populations can be sampled through food traps or corrugated cardboard pupation traps, or traps that are designed to catch adult beetles.

Plodia interpunctella can be found in stored grain commodities, though it is usually not a primary pest of those crops. In grain bins, more stored-product insects are found in samples taken from the top layer of the grain mass than from the bottom layers (Hagstrum et al., 1998). The variation in $P$. interpunctella numbers over a period of time, between grain bins, and locations within grain bins differ with the type of sampling method used. In a study by Hagstrum (2000), the majority of $P$. interpunctella were caught as adults in sticky traps placed in the head space of 
grain bins. The larvae can be distributed within the bulk mass of stored commodities, but can be spatially separated in a patchy or random distribution pattern (Nansen et al., 2004a, b).

One stored oilseed crop that is particularly vulnerable to $P$. interpunctella is stored in-shell peanuts, and in the USA $P$. interpunctella is considered to be the most important insect pest in bulk peanut storages (Arthur et al., 1988; Arthur, 1989a, b, 1994, 1995). The larvae of P. interpunctella will not penetrate a solid pod, but enter through a crack or split in the shell, and then feed on the kernel (Arthur, 1989a,b). Studies with the organophosphate chlorpyrifos-methyl and with the pyrethroid cyfluthrin show that the amount of insecticide required to kill the wandering-phase larvae will be 10-20 times greater than the amount required to kill adult Tribolium castaneum (Herbst), the red flour beetle (Arthur, 1989b, 1994, 1995). Peanuts are often stored in the shell in flat storages, and infestations of $P$. interpunctella can occur within the peanut mass. Studies in these sites also indicate a patchy or random distribution, with the greatest proportion of the population in the top of the stack and on the sides of the peanut mass next to the walls of the warehouse (Keever et al., 1985). Other fruit and nut crops that are stored in flat warehouses can also be infested with $P$. interpunctella (Johnson et al., 1992, 1995, 2002).

In recent years, there has been more emphasis on control and distribution of $P$. interpunctella in sites other than those which are storing grain or nut commodities, and many of these studies have also shown a spatially aggregated fashion (Arbogast et al., 2000, 2002). Based upon contour mapping of pheromone-baited trap records, Campbell et al. (2002) identified hot-spots, or places in which high numbers of $P$. interpunctella were found. These were near the doorways and pallet wrapping equipment in a food processing facility. Aggregated distribution could also be due to factors such as micro-climatic suitability of certain areas within a facility, interaction with biotic factors, processing practices, presence of doors and windows, and other physical attributes of a facility. Food-bait traps indicate that there is a significant correlation between some of these factors and the spatial distribution of several stored-product beetles in food processing facilities (Trematerra and Sciarretta, 2004). Knowledge of the distribution of $P$. interpunctella based upon trap catch records in a facility can help in their management. However, the use of pheromone-baited trap catch data for estimation of absolute numbers of insects, and their consequent use in spatial analysis and management, is often inaccurate and relatively poorly understood for stored-product insects (Campbell et al., 2002).

Although $P$. interpunctella is primarily associated with stored foods and not considered to be a pest of field crops, the immediate area outside of a storage facility represents an important source of infestation (Doud and Phillips, 2000). Vick et al. (1986) and Campbell and Mullen (2004) captured high numbers of $P$. interpunctella outside a food processing facility in pheromone-baited traps. However, if there are no commodities or products stored in a particular facility, breeding in the outdoor area surrounding the facility may be limited (Cogburn and Vick, 1981). Doud and Phillips (2000) recorded rapid reinfestation of $P$. interpunctella in a flour mill after fumigation with methyl bromide, and attributed this increase to immigration from outdoor infestations. Similarly, Roesli et al. (2003) recorded an increase in populations of several stored-product insects, including $P$. interpunctella, inside a flour mill, after heat treatment. Soderstrom et al. (1987) and Campbell and Arbogast (2004) found high $P$. interpunctella activity outdoors and speculated that these moths were originating from outdoor sources. In these and other field studies, the number of generations per year varied depending on climate, food source, and specific characteristics of storage sites. Field studies in the USA have shown only one to three generations of $P$. interpunctella, with a defined peak or peaks during the summer months (Arbogast et al., 2000; Johnson et al., 2000; Campbell et al., 2002; Campbell and Arbogast, 2004; Nansen et al., 2004c).

\section{Management of $\boldsymbol{P}$. interpunctella}

Management of $P$. interpunctella and other storedproduct pests is undergoing a rapid change from an insecticide-based system to a more integrated approach (Arthur and Phillips, 2003; White, 1992; White and Leesch, 1996). Amendments made to the Federal Insecticide, Fungicide and Rodenticide Act (FIFRA) as a result of passing of the Food Quality Protection Act (FQPA) in 1996 charged the USA Environmental Protection Agency to re-evaluate all currently registered pesticides. Some organophosphate and carbamate insecticides have been removed from the post-harvest market, while some others are under threat of removal. In addition, strains of $P$. interpunctella have developed resistance to the organophosphate malathion and several other organophosphates (Attia, 1977, 1981; Zettler et al., 1973, 1989; Zettler, 1982; Arthur et al., 1988; Sumner et al., 1988; Schaafsma, 1990; Subramanyam and Hagstrum, 1996; Arthur and Phillips, 2003). Plodia interpunctella has also developed resistance to the microbial insecticide Bacillus thuringiensis Berliner in laboratory selection studies, (Johnson et al., 1990; Van-Rie et al., 1990; McGaughey and Johnson, 1992; Subramanyam and Hagstrum, 1996; Herrero et al., 2001), but there is no direct evidence of field resistance.

Fumigation is an important management option and can control all stages of $P$. interpunctella in grain bins, elevators, warehouses, and other mass grain storage structures. Some $P$. interpunctella strains have developed low-levels of resistance to phosphine (Chaudhry, 1997; Zettler, 1982; Zettler et al., 1989), but the effect of these low levels of resistance on control failures is unknown. However, there have been no recent studies of phosphine resistance as it relates to $P$. interpunctella published in 
refereed journals, possibly because of the continuing decline of researchers in stored-product entomology in general, coupled with the view that resistance surveys may have little practical application when there is a limited number of insecticides that can be used. Methyl bromide, the other commonly used fumigant in stored-product pest management, is being withdrawn in most developed countries as a result of the Montreal Protocol, an international agreement (Anonymous, 2004).

Alternative or integrated control methods are being advocated as replacements or supplements for fumigants in bulk storage and in milling and processing facilities (Arthur, 1996; Dunkel and Sears, 1998; Kawakami, 1999; Toshiyuki et al., 1999; Mbata and Phillips, 2001; Mueller, 2001; Arthur and Phillips, 2003). Sanitation, improved monitoring and surveillance, surface insecticidal treatments, crack and crevice treatments, inert dusts, modified atmospheres, and heat treatments, are all mentioned as controls for $P$. interpunctella and other stored-product insects (Arthur and Phillips, 2003). Sanitation is perceived as having an effect on insect population growth in storedproduct environments (Cuperus et al., 1990; Loschiavo and Okumura, 1979; Platt et al., 1998), and may improve the effectiveness of residual insecticides (Arthur and Phillips, 2003). Plodia interpunctella larvae can invade packaged foods (Tsuji, 1998, 2000), and insect-resistant packaging can prevent entry of larval stages and oviposition by adults (Mullen, 1994; Mullen and Mowery, 2003; Sato et al., 2003). Larvae are susceptible to low-oxygen conditions through the use of modified atmospheres, but they can survive up to 6 days under such conditions (Locatelli et al., 2002).

The use of semiochemicals in stored-product pest management has been an important option for many years (Phillips, 1997; Jones, 1998; Phillips et al., 2000b; Cox, 2004). Semiochemicals are generally used in the form of sex pheromone lures for monitoring stored-product pests, but they have a broader potential for controlling insect populations as well. Semiochemicals can be used for mass trapping, attracting and killing, mating disruption, as repellents, and as specific behavioral stimulants or deterrents (Cox, 2004). Chemical attractants (Toth et al., 2002), repellents (Khan, 1981, 1983), mating disruptors, and sex stimulants (Brady et al., 1971; Ryne et al., 2001; Fadamiro and Baker, 2002; Nansen and Phillips, 2003, 2004) for $P$. interpunctella have been evaluated in research studies but do not receive widespread commercial use.

Biological control is another possibility for control of $P$. interpunctella in bulk grain and in milling and processing facilities (Brower et al., 1996; Schöller et al., 1997; Schöller and Flinn, 2000). Laboratory and field trials have been conducted with predatory insects and with hymenopteran parasites (Schöller and Flinn, 2000). Effective field control of $P$. interpunctella and other pyralid moths has been achieved with Habrabracon (Bracon) hebetor (Say) (Cline and Press, 1990; Cline et al., 1984; Press et al., 1982). Several studies indicate the presence and abundance of parasites and predators of $P$. interpunctella in and around storage facilities (Johnson et al., 2000). Wasps of the genus Trichogramma, which are egg parasites of many lepidopteran pests, have also been evaluated for control of P. interpunctella (Brower, 1990; Schöller and Flinn, 2000; Grieshop, 2005).

Low temperature storage and heat treatment of storage facilities have potential to control $P$. interpunctella (Fields, 1992). At $10^{\circ} \mathrm{C}$, a stress is imposed on adult moths, causing an increase in adult mortality; surviving adults exhibited decreased egg production and those eggs laid had lower viability (Johnson et al., 1997). One-day-old P. interpunctella eggs are more tolerant of heat treatment $\left(42-48^{\circ} \mathrm{C}\right)$ than the 2- or 3-day-old eggs, while at cold temperatures $\left(0-10.5^{\circ} \mathrm{C}\right)$ the older eggs were more resistant and took longer to die (Lewthwaite et al., 1998). Heat treatment in a pilot feed mill eliminated populations of different storedproduct insects, but the $P$. interpunctella population gradually increased after a few weeks (Roesli et al., 2003). This gradual increase in $P$. interpunctella numbers could have been due to immigration of $P$. interpunctella from outside (Doud and Phillips, 2000). Heat and cold treatments (Johnson and Wofford, 1991; Johnson et al., 1997) can be used in combination with other control methods such as modified atmospheres or application of a granulosis virus (Johnson et al., 2002).

Management of stored-product pests based on monitoring their spatio-temporal distribution is widely recommended for achieving sustained control. Such management practices could also help in slowing down resistance development by $P$. interpunctella to various newer chemicals that are currently being tested (Arbogast et al., 2002; Trematerra and Sciarretta, 2004). Many of the studies on the spatial distribution of $P$. interpunctella are based on pheromone-baited trap catches. In such studies, there is a chance for the traps to record high numbers of adults even though they are placed far apart from the actual source(s) of infestation because of the wandering behavior of the fifth instars in search of a pupation site, and also due to the dispersal behavior of the adult moths (Campbell and Arbogast, 2004). Also, the variation in P. interpunctella numbers over a period of time is related to the type of sampling method used (Hagstrum, 2000). Under these situations, when management practices are purely based on such spatial distribution data, they may not yield desirable results. Nevertheless, the relative trap catch numbers or indicative trap numbers can be used as a guide in making management decisions (Arbogast and Mankin, 1999; Arbogast et al., 2000). Food-bait traps are sometimes used in combination with pheromone-baited traps to determine the distribution of $P$. interpunctella (Cox, 2004; Trematerra and Sciarretta, 2004).

The use of natural products to control various storedproduct insects, including $P$. interpunctella is an alternative to chemical treatments and fumigation (Arthur, 1996). Diatomaceous earth (DE), a natural inert dust, and Spinosad, a naturally derived insecticide, are two grain 
protectants that are effective against the larvae of $P$. interpunctella. Up to $86-97 \%$ of first instar $P$. interpunctella were killed by the DE Insecto ${ }^{\circledR}$ applied at 500 and 1000 ppm (Subramanyam et al., 1998). Spinosad was very effective against the larvae of $P$. interpunctella; 97.6-99.6\% mortality was obtained when it was applied at 1 ppm (Fang et al., 2002). A granulosis virus has also been shown to be effective against $P$. interpunctella (Vail et al., 1991; Vail and Tebbets, 1993; Boots and Begon, 1995).

To conduct quantitative tests of the effects of several control methods on $P$. interpunctella, and to evaluate their effectiveness could be labor-intensive and time consuming. However, when some basic information, such as mortality, prolongation of development period, and reduction of progeny production due to such management practices on $P$. interpunctella becomes available, simulation modeling of the population dynamics of $P$. interpunctella has the potential to provide a powerful testing platform for many of these management methods, singly or in combination with each other (Throne, 1996).

\section{Summary and conclusions}

The behavior of $P$. interpunctella in the presence of a food source has been described in a number of publications cited earlier. However, when food is not readily accessible, or when there are no strong olfactory cues due to packaging and other barriers, $P$. interpunctella adults may lay their eggs in the vicinity of the food source so that the emerging larvae may crawl towards the food. In the absence of ready access to food, it is possible for the adults to find oviposition sites in spillage, damaged packages, and other stored-product wastes in and around a storage facility. Studies to quantify the oviposition preferences of newly emerged adults towards such alternative sites, the maximum distance from the food source that such eggs are laid, and the viability of such eggs are critical issues in population dynamics modeling, as there could be differences in the developmental biology of progeny developing outside their normal habitats.

We have shown that fecundity, development time, and other biological parameters of $P$. interpunctella are extremely variable, depending on the specific food source that was used in a particular research study. Data are lacking for many of the commodities that are commonly infested by $P$. interpunctella, such as bird seed, pet foods, and spices. Given the lack of resources and personnel in stored-product entomology, it is neither possible nor desirable to repeat studies on each and every commodity that can be infested by $P$. interpunctella. Perhaps a more promising approach is to classify the food types in to several broader categories, based on different criteria, perhaps nutrient composition (Nansen and Phillips, 2004), and quantify the biological parameters under each broader group of such commodities. If the biological parameters do not extensively vary when reared on such criterion-based commodities, this will allow researchers make more general assumptions to model biological processes for $P$. interpunctella.

Simulation models used to predict insect population growth and development often utilize stage-specific growth rates and mortalities (Birley, 1979; Flinn et al., 1986; Smith, 1992; Martinson and Dennehy, 1995; Throne et al., 2000). Data on the development time and mortality of individual instars of $P$. interpunctella is limited in the published literature, and estimation of development times, developmental threshold temperatures, and mortalities for the five larval instars of $P$. interpunctella could help in compartmentalized modeling of the life cycle. This will in turn allow pest managers to target the life stages that are particularly susceptible to control tactics and artificially simulate the effects of such a management practice on individual life stages. Modeling the population dynamics of stored-product insects may assist in the timing of management practices and can also act as an evaluation tool for a given management practice (Hagstrum and Flinn, 1990; Flinn and Hagstrum, 1990; Flinn et al., 1997). Models that simulate population dynamics have been described for different stored-product beetle species (Throne, 1996), and for Cadra (Ephestia) cautella (Walker), the almond moth, another important moth pest of stored products (Throne et al., 1998).

Several studies suggest that the population of $P$. interpunctella outside a storage facility could potentially migrate inside at the beginning of a season (Doud and Phillips, 2000; Campbell and Arbogast, 2004; Campbell and Mullen, 2004). However, there are no studies to quantify the time and spatial extent of such immigration. Dispersal is an important component of insect population dynamics. If a significant proportion of $P$. interpunctella immigration into storage facilities does occur, studies may be required to quantify the immigration into the facility and the developmental biology of $P$. interpunctella populations that are breeding outside major storage facilities. Also, most of the published studies with adult moth movements are almost exclusively done with male moths because they respond to the sex pheromones. There are almost no data on movement of adult female $P$. interpunctella in stored-product facilities.

Various aspects of the biology, behavior, and ecology of stored-product insects are influenced by their spatial distribution in different facilities, which are due to factors like different processing practices, food availability, climatic differences, and interaction among other species (Trematerra and Sciarretta, 2004). Flinn et al. (1992) simulated insect populations in grain bins by dividing the grain bins into 16 different compartments and predicting insect development in the compartments based on daily average temperature. Monitoring different spatially aggregated but independent populations of $P$. interpunctella inside a storage facility will reveal the extent to which such populations vary in their developmental biology. If significant differences exist, then different population models may be needed for a single storage facility. 
There are several new avenues of research for the control of $P$. interpunctella in bulk storage, mills, and processed food warehouses. Semiochemicals have the potential to control insect populations (Phillips, 1997; Agelopoulos et al., 1999; Ryne et al., 2001; Cox, 2004; Nansen and Phillips, 2004), and semiochemicals affecting $P$. interpunctella have already been identified and/or synthesized. Sex pheromone lures are used for monitoring purposes and there is potential for using the pheromone attractant for $P$. interpunctella to disrupt mating. Other possibilities for control include the use of attracticides for control of $P$. interpunctella populations under field conditions. Insect growth regulators (IGRs) are receiving increased attention in many agricultural systems, including stored products. The IGR hydroprene limits egg hatching and larval development of $P$. interpunctella (Arbogast et al., 2002; Mohandass et al., 2006a, b). Methoprene and pyriproxifen have recently been labeled as aerosol treatments and for some surface applications, and they may also affect $P$. interpunctella in a manner similar to hydroprene. Since resistance to IGRs by different insects is already reported in the scientific literature (Dame et al., 1998; Cornel et al., 2000, 2002; Horowitz and Ishaaya, 1994; Horowitz et al., 2002), trials to find alternative chemicals with different mode(s) of action or other management methods, and their use in rotation with IGRs, will help in slowing the development of resistance by $P$. interpunctella.

\section{Acknowledgments}

We thank J.F. Campbell, J.A. Johnson, and T.W. Phillips for reviewing an earlier version of this manuscript. We also thank R.A. Hammel and J.M. Vardeman for assistance in preparing this manuscript. This research was supported by USDA-CSREES-PMAP (Agreement No. 0034381-9557) and by USDA-CSREES-RAMP (Agreement No. 00-51101-9674). This paper is contribution No. 05134-J from Kansas Agricultural Experiment Station.

\section{References}

Agelopoulos, N., Brickett, M.A., Hick, A.J., Hooper, A.M., Pickett, J.A., Pow, E.M., Smart, L.E., Smiley, D.W.M., Wadhams, L.J., Woodcock, C.M., 1999. Exploiting semiochemicals in pest control. Pesticide Science 55, 225-235.

Allotey, J., Goswami, L., 1990. Comparative biology of two phyctid moths, Plodia interpunctella (Hübn.) and Ephestia cautella (Wlk.) on some selected food media. Insect Science and its Application 11, 209-215.

Anonymous, 2004. Notice of proposed rulemaking - protection of stratospheric ozone: process for exempting critical uses from the phaseout of methyl bromide. Federal Register 69, 55365-55402.

Arbogast, R.T., Mullen, M.A., 1978. Spatial distribution of eggs by ovipositing Indianmeal moths, Plodia interpunctella (Hübner) (Lepidoptera: Pyralidae). Researches on Population Ecology 19, 148-154.

Arbogast, R.T., Mankin, R.W., 1999. The utility of spatial analysis in management of storage pests. In: Zuxun, J., Quan, L., Yongsheng, L., Xianchang, T., Lianghua, G. (Eds.), Stored Product Protection. Proceedings of the 7th International Conference on Stored-product Protection, 14-19 October 1998, Beijing, PR China. Sichuan Publish- ing House of Science and Technology, Chengdu, PR China, pp. 1519-1527.

Arbogast, R.T., Lecato, G.L., Byrd, R.V., 1980. External morphology of some eggs of stored product moths (Lepidoptera: Pyralidae, Gelechiidae, Tineidae). International Journal of Insect Morphology and Embryology 9, 165-178.

Arbogast, R.T., Kendra, P.E., Mankin, R.W., McGovern, J.E., 2000. Monitoring insect pests in retail stores by trapping and spatial analysis. Journal of Economic Entomology 93, 1531-1542.

Arbogast, R.T., Kendra, P.E., Mankin, R.W., McDonald, R.C., 2002. Insect infestation of a botanicals warehouse in north-central Florida. Journal of Stored Products Research 38, 349-363.

Arthur, F.H., 1989a. Effects of cleaning peanuts on insect damage, insect population growth and insecticide efficacy. Peanut Science 16, $100-105$.

Arthur, F.H., 1989b. Pests of stored peanuts: toxicity and persistence of chlorpyrifos-methyl. Journal of Economic Entomology 82, 660-664.

Arthur, F.H., 1994. Efficacy of cyfluthrin, cyfluthrin + piperonyl butoxide, cyfluthrin + piperonyl butoxide + chlorpyrifos-methyl as protectants of stored peanuts. Peanut Science 21, 44-48.

Arthur, F.H., 1995. Susceptibility of 5th instar Indianmeal moth and almond moth (Lepidoptera: Pyralidae) to cyfluthrin residues on peanuts. Journal of Entomological Science 30, 318-323.

Arthur, F.H., 1996. Grain protectants: current status and prospects for the future. Journal of Stored Products Research 32, 293-302.

Arthur, F.H., Phillips, T.W., 2003. Stored-product insect pest management and control. In: Hui, Y.H., Bruinsma, B.L., Gorham, J.R., Nip, W.K., Tong, P.S., Ventresca, P. (Eds.), Food Plant Sanitation. Marcel Dekker, New York, pp. 341-358.

Arthur, F.H., Zettler, J.L., Halliday, W.R., 1988. Insecticide resistance among populations of almond moth and Indianmeal moth, (Lepidoptera: Pyralidae) in stored peanuts. Journal of Economic Entomology $81,1283-1287$.

Attia, F.I., 1977. Insecticide resistance in Plodia interpunctella (Lepidoptera: Pyralidae) in New South Wales, Australia. Journal of Australian Entomological Society 16, 149-152.

Attia, F.I., 1981. Insecticide resistance in pyralid moths of grain and stored products. General and Applied Entomology 13, 3-8.

Bell, C.H., 1975. Effects of temperature and humidity on development of four pyralid moth pests of stored products. Journal of Stored Products Research 11, 167-175.

Bell, C.H., 1976a. Factors governing the induction of diapause in Ephestia elutella and Plodia interpunctella. Physiological Entomology 1, 83-92.

Bell, C.H., 1976b. Factors influencing the duration and termination of diapause in the Indian meal moth Plodia interpunctella. Physiological Entomology 1, 93-102.

Bell, C.H., 1981. The influence of light cycle and circadian rhythm on oviposition in five pyralid moth pests of stored products. Physiological Entomology 6, 231-239.

Bell, C.H., 1982. Observations on the intensity of diapause and cold tolerance in larvae from 12 populations and 2 reciprocal crosses of the Indian meal moth Plodia interpunctella. Physiological Entomology 7, 371-378.

Bell, C.H., Walker, D.J., 1973. Diapause induction in Ephestia elutella and Plodia interpunctella (Lepidoptera. Pyralidae) with a dawn dusk lighting system. Journal of Stored Products Research 9, 149-158.

Bell, C.H., Bowley, C.R., Cogan, P.M., Sharma, S., 1979. Diapause in 23 populations of Plodia interpunctella (Lepidoptera: Pyralidae) from different parts of the world. Ecological Entomology 4, 193-198.

Birley, M.H., 1979. The estimation and simulation of variable developmental period with application to the mosquito Aedes aegypti. Researches on Population Ecology 21, 68-80.

Boots, M., Begon, M., 1995. Strain differences in the Indian meal moth, Plodia interpunctella, in response to a granulosis virus. Researches on Population Ecology 37, 37-42.

Brady, U.E., Tumlinson III, J.H., Brownlee, R.G., Silverstein, R.M., 1971. Sex stimulant and attractant in the Indian meal moth and in the almond moth. Science 171, 802-804. 
Brower, J.H., 1990. Host locating ability of Trichogramma pretiosum Riley (Hymenoptera: Trichogrammatidae) in inshell peanuts under laboratory conditions. Journal of Agricultural Entomology 7, 265-273.

Brower, J.H., Smith, L., Vail, P.V., Flinn, P.W., 1996. Biological control. In: Subramanyam, Bh., Hagstrum, D.W. (Eds.), Integrated Management of Insects in Stored Products. Marcel Dekker, New York, pp. 223-286.

Campbell, J.F., Arbogast, R.T., 2004. Stored-product insects in a flour mill: population dynamics and response to fumigation treatments. Entomologia Experimentalis et Applicata 112, 217-225.

Campbell, J.F., Mullen, M.A., 2004. Distribution and dispersal behavior of Trogoderma variable and Plodia interpunctella outside a food processing plant. Journal of Economic Entomology 97, 1455-1464.

Campbell, J.F., Mullen, M.A., Dowdy, A.K., 2002. Monitoring stored product pests in food processing plants with pheromone trapping, contour mapping and mark recapture. Journal of Economic Entomology 95, 1089-1101.

Chaudhry, M.Q., 1997. A review of the mechanisms involved in the action of phosphine as an insecticide and phosphine resistance in storedproduct insects. Pesticide Science 49, 213-228.

Cline, L.D., Press, J.W., 1990. Reduction in almond moth (Lepidoptera: Pyralidae) infestations using commercial packaging of foods in combination with the parasitic wasp, Bracon hebetor (Hymenoptera: Braconidae). Journal of Economic Entomology 83, 1110-1113.

Cline, L.D., Press, J.W., Flaherty, B.R., 1984. Preventing the spread of the almond moth (Lepidoptera: Pyralidae) from infested food debris to adjacent uninfested packages, using the parasite Bracon hebetor (Hymenoptera: Braconidae). Journal of Economic Entomology 77, 331-333.

Cogburn, R.R., Vick, K.W., 1981. Distribution of Angoumois grain moth, almond moth, and Indian meal moth, in rice fields and rice storages in Texas as indicated by pheromone-baited adhesive traps. Environmental Entomology 10, 1003-1007.

Cornel, A.J., Stanich, M.A., Farley, D., Mulligan, F.S., Byde, G., 2000. Methoprene tolerance in Aedes nigromaculis in Fresno County, California. Journal of American Mosquito Control Association 16, 223-228.

Cornel, A.J., Stanich, M.A., McAbee, R.D., Mulligan, F.S., 2002. High level methoprene resistance in the mosquito Ochlerotatus nigromaculis (Ludlow) in Central California. Pest Management Science 58, 791-798.

Cox, P.D., 1979. The importance of phycitines on imports to Britain in relation to their biology. In: Proceedings of the Second International Working Conference on Stored-Product Entomology, 10-16 September 1978, Ibadan, Nigeria, pp. 380-395.

Cox, P.D., 2004. Potential for using semiochemicals to protect stored products from insect infestation. Journal of Stored Products Research $40,1-25$.

Cuperus, G.W., Noyes, R.T., Fargo, W.S., Clary, B.L., Arnold, D.C., Anderson, N.K., 1990. Management practices in a high-risk storedwheat system in Oklahoma. American Entomologist 36, 129-134.

Dame, D.A., Wichterman, G.J., Hornby, J.A., 1998. Mosquito (Aedes taeniorhynchus) resistance to methoprene in an isolated habitat. Journal of American Mosquito Control Association 14, 200-203.

Deseo, K.V., 1976. The oviposition of the Indian meal moth (Plodia interpunctella Hbn., Lep., Phycticidae) influenced by olfactory stimuli and antennectomy. Symposium of the Biological Society of Hungary $16,61-65$.

Doud, C.W., Phillips, T.W., 2000. Activity of Plodia interpunctella (Lepidoptera: Pyralidae) in and around flour mills. Journal of Economic Entomology 93, 1842-1847.

Dunkel, F.V., Sears, L.J., 1998. Fumigant properties of physical preparations from mountain big sagebrush, Artemisia tridentata Nutt. ssp. vaseyana (Rydb.) for stored grain insects. Journal of Stored Products Research 34, 307-321.

Fadamiro, H.Y., Baker, T.C., 2002. Pheromone puffs suppress mating by Plodia interpunctella and Sitotroga cerealella in an infested corn store. Entomologia Experimentalis et Applicata 102, 239-251.
Fang, L., Subramanyam, B., Arthur, F.H., 2002. Effectiveness of spinosad on four classes of wheat against five stored-product insects. Journal of Economic Entomology 95, 640-650.

Fields, P.G., 1992. The control of stored-product insects and mites with extreme temperatures. Journal of Stored Products Research 28, $89-118$.

Flinn, P.W., Hagstrum, D.W., 1990. Simulations comparing the effectiveness of various stored-grain management practices used to control Rhyzopertha dominica (Coleoptera: Bostrichidae). Environmental Entomology 19, 725-729.

Flinn, P.W., Taylor, R.A.J., Hower, A.A., 1986. Predictive model for the population dynamics of potato leafhopper Empoasca fabae (Homoptera: Cicadellidae) on alfalfa. Environmental Entomology 15, 898-904.

Flinn, P.W., Hagstrum, D.W., Muir, W.E., Sudayappa, K., 1992. Spatial model for simulating changes in temperature and insect population dynamics in stored grain. Environmental Entomology 21, 1351-1356.

Flinn, P.W., Hagstrum, D.W., Muir, W.E., 1997. Effects of time of aeration, bin size, and latitude on insect populations in stored wheat: a simulation study. Journal of Economic Entomology 90, 646-651.

Grieshop, M.J., 2005. Evaluation of three species of Trichogramma egg parasitoids for biological control of the Indian meal moth in warehouses and retail stores. Ph.D. Thesis, Kansas State University, $227 \mathrm{pp}$.

Hagstrum, D.W., 2000. Using five sampling methods to measure insect distribution and abundance in bins storing wheat. Journal of Stored Products Research 36, 253-262.

Hagstrum, D.W., Flinn, P.W., 1990. Simulations comparing insect species differences in response to wheat storage conditions and management practices. Journal of Economic Entomology 83, 2469-2475.

Hagstrum, D.W., Flinn, P.W., Subramanyam, B., 1998. Predicting insect density from probe trap catch in farm stored wheat. Journal of Stored Products Research 34, 251-262.

Hamlin, J.C., Reed, W.D., Phillips, M.E., 1931. Biology of the Indianmeal moth on dried fruits in California. USDA Technical Bulletin No. 242, 27pp.

Heinrich, C., 1956. American moths of the subfamily Phycitinae. US National Museum Bulletin 27. US Government Printing Office, Washington, DC, 581pp.

Herrero, S., Oppert, B., Ferre, J., 2001. Different mechanisms of resistance to Bacillus thuringiensis toxins in the Indianmeal moth. Applied and Environmental Microbiology 67, 1085-1089.

Hinton, H.E., 1943. The larvae of Lepidoptera associated with stored products. Bulletin of Entomological Research 34, 163-212.

Horowitz, A.R., Ishaaya, I., 1994. Managing resistance to insect growth regulators in the sweetpotato whitefly (Homoptera: Aleyrodidae). Journal of Economic Entomology 87, 866-871.

Horowitz, A.R., Kontsedalov, S., Denholm, I., Ishaaya, I., 2002. Dynamics of insecticide resistance in Bemisia tabaci: a case study with the insect growth regulator pyriproxyfen. Pest Management Science $58,1096-1100$.

Howe, W.E., 1965. A summary of estimates of optimal and minimal conditions for population increase of some stored products insects. Journal of Stored Products Research 1, 177-184.

Johnson, D.E., Brookhart, G.L., Kramer, K.J., Barnett, B.D., McGaughey, W.H., 1990. Resistance to Bacillus thuringiensis by the Indian meal moth, Plodia interpunctella: comparison of midgut proteinases from susceptible and resistant larvae. Journal of Invertebrate Pathology 55, 235-244.

Johnson, J.A., Wofford, P.L., 1991. Effects of age on response of eggs of Indianmeal moth and navel orangeworm (Lepidoptera: Pyralidae) to subfreezing temperatures. Journal of Economic Entomology 84, 202-205.

Johnson, J.A., Wofford, P.L., Whitehand, L.C., 1992. Effect of diet and temperature on development rates, survival and reproduction of the Indianmeal moth (Lepidoptera: Pyralidae). Journal of Economic Entomology 85, 561-566. 
Johnson, J.A., Wofford, P.L., Gill, R.F., 1995. Developmental thresholds and degree-day accumulations of Indianmeal moth (Lepidoptera: Pyralidae) on dried fruits and nuts. Journal of Economic Entomology 88, 734-741.

Johnson, J.A., Valero, K.A., Hannel, M.M., 1997. Effect of low temperature storage on survival and reproduction of Indianmeal moth (Lepidoptera: Pyralidae). Crop Protection 16, 519-523.

Johnson, J.A., Valero, K.A., Hannel, M.M., Gill, R.F., 2000. Seasonal occurrence of postharvest dried fruit insects and their parasitoids in a culled fig warehouse. Journal of Economic Entomology 93, $1380-1390$.

Johnson, J.A., Vail, P.V., Brandl, D.G., Tebbets, J.S., Valero, K.A., 2002. Integration of nonchemical treatments for control of postharvest pyralid moths (Lepidoptera: Pyralidae) in almonds and raisins. Journal of Economic Entomology 95, 190-199.

Jones, O.T., 1998. Practical applications of pheromones and other semiochemicals. In: House, P.E., Stevens, I.D.R., Jones, O.T. (Eds.), Insect Pheromones and their Use in Pest Management. Chapman \& Hall, London, pp. 263-355.

Kawakami, F., 1999. Current research of alternatives to methyl bromide and its reduction in Japanese plant quarantine. Research Bulletin of the Plant Protection Service Japan 35, 109-120.

Keever, D.W., Arbogast, R.T., Mullen, M.A., 1985. Population trends and distributions of Bracon hebetor Say (Hymenoptera: Braconidae) and lepidopterous pests in commercially stored peanuts. Environmental Entomology 14, 722-725.

Khan, M.A., 1981. Repellents against stored product insects. Anzeiger für Schaedlingskunde Pflanzenschutz Umweltschutz 54, 70-77.

Khan, M.A., 1983. Repellency of chemical compounds to stored product insect pests. Zeitschrift für Angewandte Zoologie 70, 369-382.

Lewthwaite, S.E., Dentener, P.R., Alexander, S.M., Bennett, K.V., Rogers, D.J., MainDonald, J.H., Connolly, P.G., 1998. High temperature and cold storage treatments to control Indian meal moth, Plodia interpunctella (Hübner). Journal of Stored Products Research 34, 141-150.

Locatelli, D.P., Caimi, M., Brumen, G., 2002. Susceptibility of Plodia interpunctella (Hbn.) and Lasioderma serricorne (F.) to nitrogen protective pressurized atmosphere. Bollettino di Zoología Agraria e di Bachicoltura 34, 361-368.

Loschiavo, S.R., Okumura, G.T., 1979. A survey of stored product insects in Hawaii USA. Proceedings of the Hawaiian Entomological Society 23, 95-118.

Madrid, F.J., Sinha, R.N., 1983. Movement and oviposition of Ephestia cautella and Plodia interpunctella (Lepidoptera: Pyralidae) of different ages in response to seasonal light changes. Canadian Journal of Zoology 61, 1726-1732.

Martinson, T.E., Dennehy, T.J., 1995. Influence of temperature-driven phenology and photoperiodic induction of reproductive diapause on population dynamics of Erythroneura comes (Homoptera: Cicadellidae). Environmental Entomology 24, 1504-1514.

Mason, L., 2003. Insects and mites. In: Hui, Y.H., Bruinsma, B.L., Gorham, J.R., Nip, W.K., Tong, P.S., Ventresca, P. (Eds.), Food Plant Sanitation. Marcel Dekker, New York, pp. 293-315.

Mbata, G.N., 1985. Some physical and biological factors affecting oviposition by Plodia interpunctella (Hübner) (Lepidoptera: Phycitidae). Insect Science and its Application 6, 597-604.

Mbata, G.N., 1987. Studies on induction of larval diapause in a Nigerian strain of Plodia interpunctella Hübner (Lepidoptera: Pyralidae). Insect Science and its Application 8, 317-322.

Mbata, G.N., Osuji, F.N.C., 1983. Some aspects of the biology of Plodia interpunctella (Lepidoptera: Pyralidae) a pest of stored groundnuts in Nigeria. Journal of Stored Products Research 19, 141-151.

Mbata, G.N., Phillips, T.W., 2001. Effects of temperature and exposure time on mortality of stored-product insects exposed to low pressure. Journal of Economic Entomology 94, 1302-1307.

McGaughey, W.H., Johnson, D.E., 1992. Indianmeal moth (Lepidoptera: Pyralidae) resistance to different strains and mixtures of Bacillus thuringiensis. Journal of Economic Entomology 85, 1594-1600.
Mohandass, S., Arthur, F.H., Zhu, K.Y., Throne, J.E., 2006a. Hydroprene prolongs developmental time and increases mortality of Indianmeal moth (Lepidoptera: Pyralidae) eggs. Journal of Economic Entomology 99, 1007-1016.

Mohandass, S., Arthur, F.H., Zhu, K.Y., Throne, J.E., 2006b. Hydroprene prolongs developmental time and increases mortality in wandering-phase Indianmeal Moth (Lepidoptera: Pyralidae) larvae. Journal of Economic Entomology 99, 1509-1519.

Mueller, D.K., 2001. Methyl bromide alternatives in developing countries. International Pest Control 43, 246-247.

Mullen, M.A., 1994. Rapid determination of the effectiveness of insect resistant packaging. Journal of Stored Products Research 30, 95-97.

Mullen, M.A., Arbogast, R.T., 1977. Influence of substrate on oviposition by 2 species of stored product moths. Environmental Entomology 6, 641-644.

Mullen, M.A., Dowdy, A.K., 2001. A pheromone-based trap for monitoring the Indian meal moth, Plodia interpunctella (Hübner) (Lepidoptera: Pyralidae). Journal of Stored Products Research 37, 231-235.

Mullen, M.A., Mowery, S.V., 2003. Packaging. In: Hui, Y.H., Bruinsma, B.L., Gorham, J.R., Nip, W.K., Tong, P.S., Ventresca, P. (Eds.), Food Plant Sanitation. Marcel Dekker, New York, pp. 423-433.

Nansen, C., Phillips, T.W., 2003. Ovipositional responses of the Indianmeal moth, Plodia interpunctella (Hübner) (Lepidoptera: Pyralidae) to oils. Annals of the Entomological Society of America 96, 524-531.

Nansen, C., Phillips, T.W., 2004. Attractancy and toxicity of an attracticide for Indianmeal moth, Plodia interpunctella (Lepidoptera: Pyralidae). Journal of Economic Entomology 97, 703-710.

Nansen, C., Phillips, T.W., Palmer, M.W., 2004a. Analysis of the insect community in a stored-maize facility. Ecological Research 19, 197-207.

Nansen, C., Phillips, T.W., Sanders, S., 2004b. Effects of height and adjacent surfaces on captures of Indianmeal moth (Lepidoptera: Pyralidae) in pheromone-baited traps. Journal of Economic Entomology 97, 1284-1290.

Nansen, C., Phillips, T.W., Parajulee, M.N., Franqui, R.A., 2004c. Comparison of direct and indirect sampling procedures for Plodia interpunctella in a maize storage facility. Journal of Stored Products Research 40, 151-168.

Phillips, T.W., 1997. Semiochemicals of stored-product insects: research and applications. Journal of Stored Products Research 33, 17-30.

Phillips, T.W., Strand, M.R., 1994. Larval secretions and food odors affect orientation in female Plodia interpunctella. Entomologia Experimentalis et Applicata 71, 185-192.

Phillips, T.W., Berbert, R.C., Cuperus, G.W., 2000a. Post-harvest integrated pest management. In: Francis, F.J. (Ed.), Encyclopedia of Food Science and Technology. 2nd ed. Wiley Inc., New York, pp. 2690-2701.

Phillips, T.W., Cogan, P.M., Fadamiro, H.Y., 2000b. Pheromones. In: Subramanyam, B., Hagstrum, D.W. (Eds.), Alternatives to Pesticides in Stored-product IPM. Kluwer Academic Publishers, London, pp. 273-302.

Platt, R.R., Cuperus, G.W., Payton, M.E., Bonjour, E.L., Pinkston, K.N., 1998. Integrated pest management perceptions and practices and insect populations in grocery stores in South-central United States. Journal of Stored Products Research 34, 1-10.

Press, J.W., Cline, L.D., Flaherty, B.R., 1982. A comparison of two parasitoids, Bracon hebetor (Hymenoptera: Braconidae) and Venturia canescens (Hymenoptera: Ichneumonidae), and a predator Xylocoris flavipes (Hemiptera: Anthocoridae) in suppressing residual populations of the almond moth, Ephestia cautella (Lepidoptera: Pyralidae). Journal of the Kansas Entomological Society 55, 725-728.

Prevett, P.F., 1971. Some laboratory observations on the development of two African strains of Plodia interpunctella (Hübner) (Lepidoptera: Pyralidae) with particular reference to the induction of diapause. Journal of Stored Products Research 7, 253-260.

Rees, D., 2004. Insects of Stored Products. CSIRO Publishing, Collingwood, Victoria, Australia. 
Richards, O.W., Thomson, W.S., 1932. A contribution to the study of Ephestia Gn. (Including Strymax dyar) and Plodia Gn. (Lepidoptera: Phyctidae), with notes on parasites of the larvae. Transactions of the Royal Entomological Society of London 80, 169-248.

Roesli, R., Subramanyam, B., Fairchild, F.J., Behnke, K.C., 2003. Trap catches of stored-product insects before and after heat treatment in a pilot feed mill. Journal of Stored Products Research 39, 521-540.

Ryne, C., Svensson, G.P., Lofstedt, C., 2001. Mating disruption of Plodia interpunctella in small-scale plots: effects of pheromone blend, emission rates, and population density. Journal of Chemical Ecology 27, 2109-2124

Sato, H., Shirai, Y., Tanaka, S., Imamura, T., Miyanoshita, M., 2003. The effect of sealing tightness of chocolate carton outer covering film on invasion by Plodia interpunctella (Hübner) (Lepidoptera: Pyralidae). Japanese Journal of Applied Entomology and Zoology 47, 97-100.

Schaafsma, A.W., 1990. Resistance to malathion in populations of Indian meal moth, Plodia interpunctella (Lepidoptera: Pyralidae). Proceedings of the Entomological Society of Ontario 121, 101-104.

Schöller, M., Flinn, P.W., 2000. Parasitoids and predators. In: Subramanyam, B., Hagstrum, D.W. (Eds.), Alternatives to Pesticides in Stored-product IPM. Kluwer Academic Publishers, Norwell, MA, pp. 229-271.

Schöller, M., Prozell, S., Al-Kirshi, A.G., Reichmuth, C., 1997. Towards biological control as a major component of integrated pest management in stored product protection. Journal of Stored Products Research 33, 81-97.

Schulten, G.G.M., Roorda, F.A., 1984. Storage insects in imported products mainly of tropical origin. Entomologische Berichten 44, 65-69.

Sedlacek, J.D., Weston P. A., BarneyJ., 1996. Lepidoptera and Psocoptera. In: Subramanyam, Bh., Hagstrum, D.W. (Eds.), Integrated Management of Insects in Stored Products. Marcel Dekker, Inc., New York, pp. 41-70.

Silhacek, D., Murphy, C., Arbogast, R.T., 2003. Behavior and movements of Indian meal moths (Plodia interpunctella Hübner) during commodity infestation. Journal of Stored Products Research 39, 171-184.

Smith, A.M., 1992. Modelling the development and survival of eggs of pea weevil (Coleoptera: Bruchidae). Environmental Entomology 21, 314-321.

Soderstrom, E.L., Hinsch, R.T., Bongers, A.J., Brandl, D.G., Hoogendorn, H., 1987. Detecting adult Phycitinae (Lepidoptera: Pyralidae) infestations in a raisin-marketing channel. Journal of Economic Entomology 80, 1229-1232.

Subramanyam, Bh., Hagstrum, D.W., 1993. Predicting development times of six stored-product moth species (Lepidoptera: Pyralidae) in relation to temperature, relative humidity, and diet. European Journal of Entomology 90, 51-64.

Subramanyam, Bh., Hagstrum, D.W., 1996. Resistance measurement and management. In: Subramanyam, B., Hagstrum, D.W. (Eds.), Integrated Management of Insects in Stored Products. Marcel Dekker, Inc., New York, pp. 331-397.

Subramanyam, Bh., Madamanchi, N., Norwood, S., 1998. Effectiveness of Insecto applied to shelled maize against stored-product insect larvae. Journal of Economic Entomology 91, 280-286.

Sumner, W.A., Harein, P.K., Subramanyam, B., 1988. Malathion resistance in larvae of some southern Minnesota USA populations of the Indian meal moth Plodia interpunctella, (Lepidoptera: Pyralidae) infesting bulk-stored shelled corn. Great Lakes Entomologist 21, $133-138$.

Throne, J.E., 1996. Computer modeling of the population dynamics of stored-product pests. In: Jayas, D.S., White, N.D.G., Muir, W.E. (Eds.), Stored Grain Ecosystems. Marcel Dekker, Inc., New York, pp. 169-195.
Throne, J.E., Hagstrum, D.W., Nawrot, J., 1998. Computer model for simulating almond moth (Lepidoptera: Pyralidae) population dynamics. Environmental Entomology 27, 344-354.

Throne, J.E., Parajulee, M.N., Phillips, T.W., 2000. Computer model for simulating population dynamics of the predator Lyctocoris campestris (Heteroptera: Anthocoridae) in stored shelled corn. Environmental Entomology 29, 1236-1243.

Toshiyuki, D., Masaki, S., Matsuoka, I., Masahiro, T., Toshitatsu, T., 1999. Low temperature as an alternative to fumigation for disinfesting stored products. Research Bulletin of the Plant Protection Service, Japan 35, 5-14.

Toth, M., Repasi, V., Szocs, G., 2002. Chemical attractants for females of pest pyralids and phycitids (Lepidoptera: Pyralidae, Phycitidae). Acta Phytopathologica et Entomologica Hungarica 37, 375-384.

Trematerra, P., Sciarretta, A., 2004. Spatial distribution of some beetles infesting a feed mill with spatio-temporal dynamics of Oryzaephilus surinamensis, Tribolium castaneum and Tribolium confusum. Journal of Stored Products Research 40, 363-377.

Tsuji, H., 1959. Studies on the diapause of the Indian-meal moth, Plodia interpunctella (Hübner). II. The effect of population density on the induction of diapause. Japanese Journal of Applied Entomology and Zoology 3, 34-40 (In Japanese with an English summary).

Tsuji, H., 1998. Experimental invasion of a food container by first-instar larvae of the Indian meal moth, Plodia interpunctella Hübner, through pinholes. Medical Entomology and Zoology 49, 99-104.

Tsuji, H., 2000. Ability of first instar larvae of the Indian meal moth, Plodia interpunctella Hübner, to reach their food. Medical Entomology and Zoology 51, 283-287.

Tzanakakis, M.E., 1959. An ecological study of the Indian meal moth, Plodia interpunctella, with emphasis on diapause. Hilgardia 29, 205-246.

Van-Rie, J., McGaughey, W.H., Johnson, D.E., Barnett, B.D., VanMellaer, T.H., 1990. Mechanism of insect resistance to the microbial insecticide Bacillus thuringiensis. Science 247, 72-74.

Vail, P.V.D.F., Tebbets, J.S., 1993. Autodissemination of Plodia interpunctella (Hübner) (Lepidoptera: Pyralidae) granulosis virus by healthy adults. Journal of Stored Products Research 29, 71-74.

Vail, P.V., Tebbets, J.S., Cowan, D.C., Jenner, K.E., 1991. Efficacy and persistence of a Granulosis virus against infestations of Plodia interpunctella (Hübner) (Lepidoptera: Pyralidae) on raisins. Journal of Stored Products Research 27, 103-107.

Vick, K.W., Koehler, P.G., Neal, J.J., 1986. Incidence of stored-product Phycitinae moth in food distribution warehouses as determined by sex pheromone-baited traps. Journal of Economic Entomology 79, 936-939.

White, N.D.G., 1992. A multidisciplinary approach to stored-grain research. Journal of Stored Products Research 28, 127-137.

White, N.D.G., Leesch, J.G., 1996. Chemical control. In: Subramanyam, B., Hagstrum, D.W. (Eds.), Integrated Management of Insects in Stored Products. Marcel Dekker, Inc., New York, pp. 287-329.

Williams, G.C., 1964. The life-history of the Indian meal-moth, Plodia interpunctella (Hübner) (Lep. Phycitidae) in a warehouse in Britain and on different foods. Annals of Applied Biology 53, 459-475.

Zettler, J.L., 1982. Insecticide resistance in selected stored product insects infesting peanuts in the Southeastern USA. Journal of Economic Entomology 75, 359-362.

Zettler, J.L., McDonald, L.L., Redlinger, L.M., Jones, R.D., 1973. Plodia interpunctella and Cadra cautella resistance in strains to malathion and synergized pyrethrins. Journal of Economic Entomology 66, 1049-1050.

Zettler, J.L., Halliday, W.R., Arthur, F.H., 1989. Phosphine resistance in insects infesting stored peanuts in the Southeastern USA. Journal of Economic Entomology 82, 1508-1511. 